\title{
Orbit Embryonal Rhabdomyosarcoma
}

National Cancer Institute

\section{Source}

National Cancer Institute. Orbit Embryonal Rhabdomyosarcoma. NCI Thesaurus. Code C6246.

A malignant mesenchymal neoplasm that arises from the orbit. It is characterized by the presence of skeletal muscle tissue exhibiting embryonic features. 